\title{
LACTOFERRIN, A MAJOR SOLUBLE PROTEIN OF BOVINE OESTROUS CERVICAL MUCUS
}

\author{
K. S. P. BHUSHANA RAO, T. K. ROBERTS, P. L. MASSON \\ AND J. F. HEREMANS \\ Department of Experimental Medicine, University of Louvain, \\ Avenue Chapelle-aux-Champs 4, B-1200 Bruxelles, Belgium
}

(Received 18th May 1972)

In 1939, Sørensen \& Sørensen discovered a red protein in bovine milk. This component, now usually called lactoferrin, is a glycoprotein with a $\gamma$-electrophoretic mobility, and consists of a single polypeptide chain with a molecular weight of 77,000. Like serum transferrin, it binds two ferric ions, but it differs in its amino acid composition, immunological properties and in the higher stability of its iron-complex at acid $\mathrm{pH}$. These features apply to bovine as well as to human lactoferrin (Groves, 1960; Johansson, 1960; Montreuil, Tonnelat \& Mullet, 1960; Blanc \& Isliker, 1961; Masson \& Heremans, 1968; Castellino, Fish \& Mann, 1970; Querinjean, Masson \& Heremans, 1971).

In the human, lactoferrin is not only found in milk but also occurs in other external secretions. It is synthesized by three types of tissues: the acini of certain glandular epithelia such as those from the bronchial mucosa and the salivary, lachrymal and mammary glands; the tubules of the kidney; and those myeloid cells which give rise to neutrophil leucocytes (Masson \& Heremans, 1966; Masson, Heremans, Prignot \& Wauters, 1966; Masson, Heremans, Schonne \& Crabbé, 1968; Masson, Heremans \& Schonne, 1969). Bovine lactoferrin has been shown to occur in the milk (Morrison \& Allen, 1966) and the secretions from Harderian and lachrymal glands, but data are lacking on its presence or absence in other fluids. In other mammals, only milk and extracts of leucocytes have been studied with respect to their lactoferrin content (Masson et al., 1969; Baggiolini, de Duve, Masson \& Heremans, 1970; Masson \& Heremans, 1971).

When a pool of bovine oestrous cervical mucus was filtered on Sepharose 6B, equilibrated with $0.1 \mathrm{M}$-tris buffer $(\mathrm{pH} 8)$ containing $2 \mathrm{M}-\mathrm{NaCl}$, it resolved into two peaks. The first peak was eluted with the void volume and corresponded chiefly to sparingly soluble mucins. The second peak, after concentration by ultrafiltration, had a pinkish hue. Electrophoresis on cellulose acetate in barbitone buffer ( $\mathrm{pH} 8 \cdot 6$ ) showed three distinct bands and one diffuse zone, when stained with Ponceau S (Pl. 1, Fig. 1). The leading band migrated as albumin and according to immunoelectrophoresis, the diffuse zone corresponded to immunoglobulins. The slowest band could have been lysozyme as its cathodal mobility was identical to that of the corresponding enzyme in the human. The major band of $\gamma$-mobility was an iron-binding protein. After addition of $\left[{ }^{59} \mathrm{Fe}\right]$ citrate, this band showed up on the X-ray film exposed to the 
cellulose acetate membrane (Pl. 1, Fig. 1) and a second, fainter and faster band was also seen. This additional iron-binding component had the electrophoretic mobility of serum transferrin and probably corresponded to this protein.

A rabbit was given three injections of purified red protein from bovine cervical mucus. The resulting antiserum produced a single precipitin line of complete identity with bovine cervical secretion as well as with bovine milk whey (Pl. 1, Fig. 2). Similar single fusing precipitates were obtained with the same fluids using rabbit antiserum to lactoferrin from bovine milk (Pl. 1, Fig. 2). Autoradiographs demonstrated that all these lines carried radioactivity when $\left[{ }^{59} \mathrm{Fe}\right]$ citrate had been added to the samples. By means of immunoelectrophoresis, it was also shown that the radioactive antigen corresponded to the main iron-carrying compound observed on the electrophoresis strips.

A further argument in favour of the lactoferrin nature of the main ironbinding protein of cervical mucus was the stability of its iron complex after dialysis of the sample against $0 \cdot 1 \mathrm{M}$-citrate buffer at $\mathrm{pH} 4 \cdot 6$ (Pl. 1, Fig. 1). After such treatment, the autoradiography of the electrophoresis still revealed the band of lactoferrin whereas the transferrin band had lost its radioactivity (P1. 1, Fig. 1).

Lactoferrin was determined by radial immunodiffusion in samples of oestrous mucus collected from nine cows. In order to prevent diffusion problems that might arise from electrostatic interactions between mucins and lactoferrin (Masson et al., 1969), agarose gels were prepared in $2 \mathrm{M}$-sodium chloride. Standards consisted of lactoferrin from cervical mucus. The concentration of lactoferrin in nine specimens of whole cervical mucus ranged from 50 to 600 $\mu \mathrm{g} / \mathrm{ml}$, with a mean of $250 \mu \mathrm{g} / \mathrm{ml}$. As estimated in a pilot experiment, $100 \mathrm{ml}$ cervical mucus yielded $280 \mathrm{mg}$ non-dialysable material. From this, about 225 $\mathrm{mg}(80 \%)$ were recovered from the column of Sepharose. Among the macromolecules thus separated, mucins accounted for $160 \mathrm{mg}(70 \%)$ and soluble proteins for $65 \mathrm{mg}(30 \%)$. Lactoferrin can therefore be considered a major protein of the soluble fraction of bovine cervical mucus, representing about $40 \%$ of its soluble material. The concentrations of lactoferrin in bovine and human cervical mucus are of the same order of magnitude. In samples collected from seven women during mid-cycle, the concentrations of lactoferrin (Masson, 1970) ranged from 80 to $1000 \mu \mathrm{g} / \mathrm{ml}$ with a mean of $350 \mu \mathrm{g} / \mathrm{ml}$.

Three sources can be envisaged for cervical lactoferrin. Firstly, neutrophil leucocytes are known to contain 3.4 $\mu \mathrm{g}$ lactoferrin $/ 10^{6}$ cells in the human (Masson et al., 1969) and these cells frequently abound in cervical mucus. This, however, may not apply to the bovine species since we have been unable to show any marked invasion of bovine cervical mucus samples by polymorphonuclear leucocytes. Secondly, although human endometrial glands contain lactoferrin, as shown by immunofluorescence (Masson, Heremans \& Ferin, 1968), this protein is detectable only at the end of the cycle. An endometrial origin for lactoferrin in oestrous cervical mucus, therefore, appears improbable. Thirdly, on histological grounds, cervical glands seem to be the most likely source of lactoferrin. We have failed to detect lactoferrin in human cervical glands by immunofluorescence, but positive results have been reported (Tomasi, 


\section{PLATE 1}

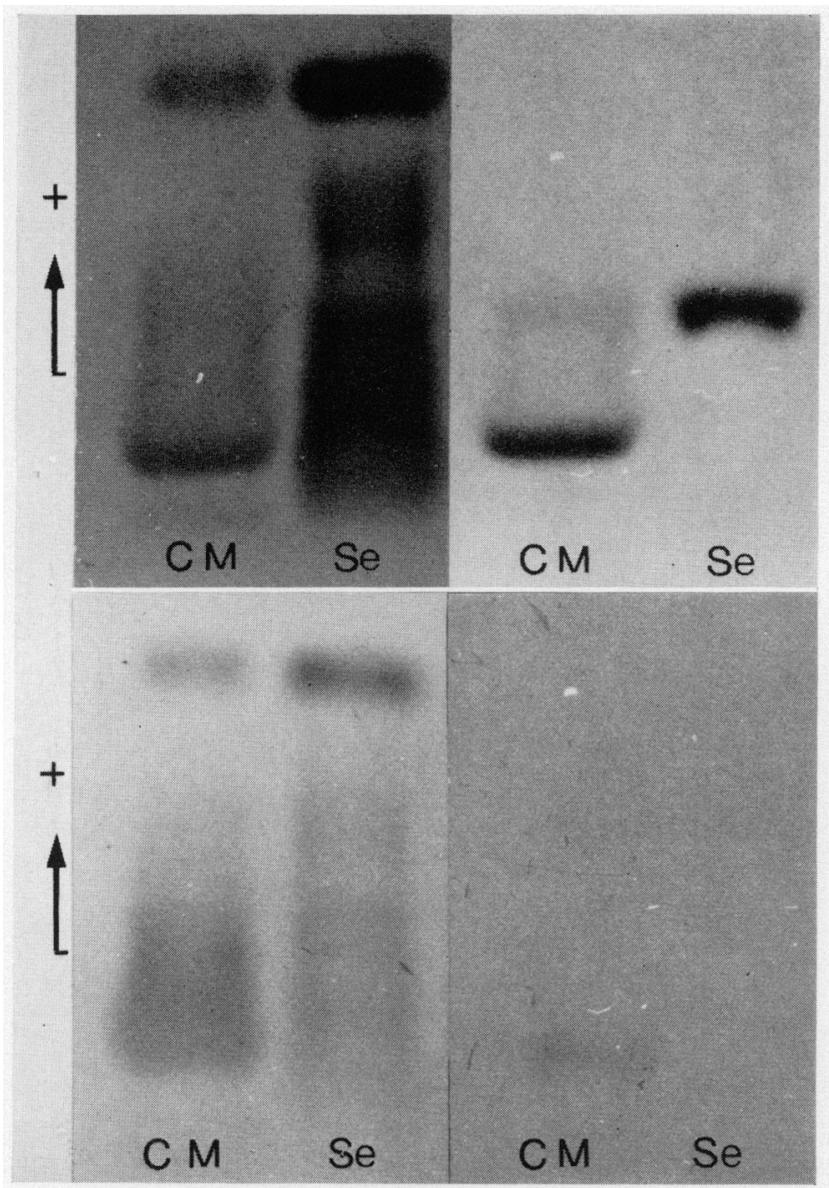

Fig. 1. Upper figure: electrophoresis on cellulose acetate at $\mathrm{pH} 8.6$ (left) and the corresponding autoradiography (right) of soluble proteins from bovine cervical mucus (GM) and of bovine serum (Se) supplemented with ${ }^{59} \mathrm{Fe}$. Lower figure: repetition of above procedure using ${ }^{59} \mathrm{Fe}$-labelled samples dialysed against $0 \cdot 1$ м-citrate buffer $\mathrm{pH} 4 \cdot 6$, before electrophoresis.

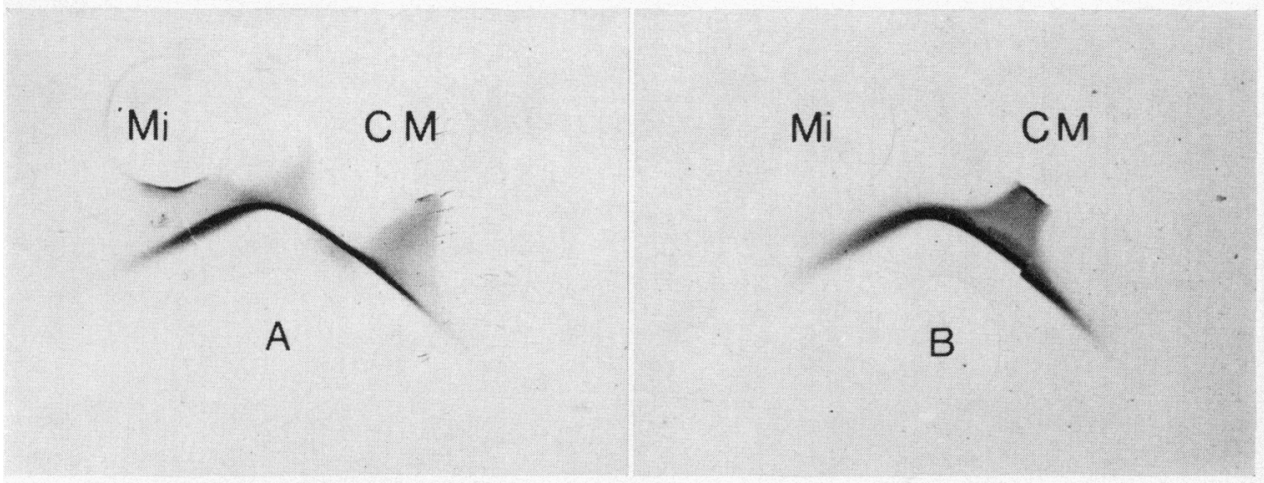

FIG. 2. Immunodiffusion plate showing the fusion between the precipitin lines produced by rabbit antisera against lactoferrin from milk (A) and from cervical mucins (B) with bovine milk whey (Mi) and with soluble proteins from bovine cervical mucus (CM).

(Facing p. 90) 
Bull, Tourville, Montes \& Yurchak, 1971), and ${ }^{14}$ C-labelled amino acids have been found to be incorporated into lactoferrin by human cervical mucosa (Masson, 1970).

The rôle of lactoferrin may be concerned with the protection of mucosa against infection. Like transferrin (Schade \& Caroline, 1944; Schade, 1960, 1963), lactoferrin (Masson et al., 1966) has been shown to inhibit the growth of various bacteria by depriving the culture medium of its iron. Some recent experiments (Bullen, Rogers \& Lewin, 1971; Bullen, Rogers \& Leigh, 1972) have shown a synergistic action of both serum transferrin and lactoferrin with antibodies. It seems possible that lactoferrin may participate in the same manner with secretory $\operatorname{IgA}$ in the antibacterial defence of the cervix.

This investigation was supported by grants $66-425$ from the Ford Foundation and FRSM-119/2. We thank Dr K. L. Smith, Ohio Agricultural Research and Development Center, Wooster, Ohio 44691, for a gift of antiserum against lactoferrin from bovine milk. Our thanks are also due to Dr C. Meeus for providing bovine oestrous mucous secretions, and to Mr E. Van Roost for his technical assistance.

\section{REFERENCES}

Baggiolint, M., de Duve, C., Masson, P. L. \& Heremans, J. F. (1970) Association of lactoferrin with specific granules in rabbit heterophil leukocytes. F. exp. Med. 131, 559.

BlANG, B. \& Istrker, H. (1961) Isolément et caractérisation de la protéine rouge sidérophile du lait maternel: la lactoferrine. Bull. Soc. Chim. biol. 43, 929.

BULLEN, J.J., ROGERs, H.J. \& LEIGH, L. (1972) Iron-binding proteins in milk and resistance to Escherichia coli infection in infants. Br. Med. 7. i, 69.

Bullen, J. J., Rogers, H. J. \& Lewin, J. E. (1971) The bacteriostatic effect of serum on Pasteurella septica and its abolition by iron compounds. Immunology, 20, 391.

Castellino, F. J., Fish, W. W. \& MANN, K. G. (1970) Structural studies on bovine lactoferrin. F. biol. Chem. 245, 4269 .

Groves, M. L. (1960) The isolation of a red protein from milk. F. Am. chem. Soc. 82, 3345.

Johansson, B. (1960) Isolation of an iron-containing red protein from human milk. Acta chem. scand. 14, 510 .

Masson, P. L. (1970) In : La Lactoferrine, pp. 93-146. Editions Arscia, Bruxelles.

Masson, P. L. \& Heremans, J. F. (1966) Studies on lactoferrin, the iron-binding protein of secretions, Protides biol. Fluids, 14, 115.

Masson, P. L. \& Heremans, J. F. (1968) Metal-combining properties of human lactoferrin (red milk protein). I. The involvement of bicarbonate in the reaction. Eur. F. Biochem. 6, 579.

Masson, P. L. \& Heremans, J. F. (1971) Lactoferrin in milk from different species. Comp. Biochem. Physiol. 39B, 119.

Masson, P. L., Heremans, J. F. \& Ferin, J. (1968) Presence of an iron-binding protein (lactoferrin) in the genital tract of the human female. I. Its immunohistochemical localization in the endometrium. Fert. Steril. 19, 679.

Masson, P. L., Heremans, J. F., Prignot, J. J. \& Wauters, G. (1966) Immunohistochemical localisation and bacteriostatic properties of an iron-binding protein from bronchial mucus. Thorax, 21, 538 .

Masson, P. L., Heremans, J. F. \& Schonne, E. (1969) Lactoferrin, an iron-binding protein in neutrophilic leukocytes. J. exp. Med. 130, 643.

Masson, P. L., Heremans, J. F., Schonne, E. \& Crabbe, P.A. (1968) New data on lactoferrin, the iron-binding protein of secretions. Protides biol. Fluids, 16, 633.

Montreuil, J., Tonnelat, J \& Muller, S. (1960) Préparation et propriétés de la lactosidérophiline (lactotransferrine) du lait de femme. Biochim. biophys. Acta, 45, 413.

MorRison, M. \& AlleN, P. Z. (1966) Lactoperoxidase: identification and isolation from Harderian and lacrimal glands. Science, $\mathcal{N}$.Y. 152, 1626.

Querinjean, P., Masson, P. L. \& Heremans, J. F. (1971) Molecular weight, single-chain structure and amino acid composition of human lactoferrin. Eur. F. Biochem. 20, 420. 
Schade, A. L. (1960) The microbiological activity of siderophilin. Protides biol. Fluids, 8, 261.

Schade, A. L. (1963) Significance of serum iron for the growth, biological characteristics and metabolism of Staphylococcus aureus. Biochem. Z. 338, 140.

Schade, A. L. \& Caroline, L. (1944) Raw hen egg white and role of iron in growth inhibition of Shigella disenteriae, Staphylococcus aureus, Escherichia coli and Saccharomyces cerevisiae. Science, N.Y. $100,14$.

Sørensen, M. \& Sørensen, S. P. L. (1939) The proteins in whey. C. R. Lab. Carlsberg, 23, 55.

Tomasi, T. B., Bull, D., Tourville, D., Montes, M. \& Yurchak, A. (1971) Distribution and synthesis of human secretory components. In: The Secretory Immunologic System. Eds. D. H. Dayton, P. A. Small, R. M. Ghanock, H. E. Kaufman and T. B. Tomasi. U.S. Government Printing Office, Washington DC. 